\title{
Readings in Epistemology
}





\title{
READINGS IN \\ EPISTEMOLOGY
}

\author{
from \\ Aquinas, \\ Bacon, Galileo, Descartes, \\ Locke, Berkeley, Hume, \\ Kant
}

\author{
by \\ VINCENT G. POTTER
}

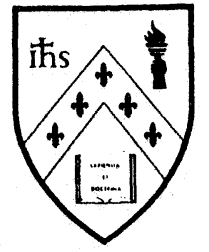

Fordham University Press

New York 
Copyright 1993 by Fordham University Press

All rights reserved

LC $92-45079$

ISBN 0-8232-1493-1 (clothbound)

ISBN 0-8232-1492-3 (paperback)

Sixth Printing, 2004

Library of Congress Cataloging-in-Publication Data

Readings in epistemology : from Aquinas, Bacon, Galileo, Descartes, Locke, Berkeley, Hume, Kant / introduction and selection by Vincent G. Potter. - 2nd ed. rev.

p. $\quad \mathrm{cm}$.

Includes bibliographical references.

ISBN 0-8232-1493-1. — ISBN 0-8232-1492-3 (pbk.)

1. Knowledge, Theory of. I. Potter, Vincent G. BD161.R342 1993

$121-\mathrm{dc} 20$

92-45079

CIP

Printed in the United States of America 
To

MY TEACHERS

who taught me to read

the great philosophers

respectfully

but critically 


\section{,}

